\title{
Hospital Pharmacy Practice and Drug Management System of Khulna Division, Bangladesh: Results from a Cross-sectional Study
}

\author{
Asma Akhter ${ }^{1}$, Safayet Jamil ${ }^{1}$, Md. Jamal Hossain ${ }^{2}$, Md. Monirul Islam², Quazi \\ Istiaque Bari $^{1}$ and Ms. Afroza Sultana ${ }^{1}$ \\ ${ }^{1}$ Department of Pharmacy, Khwaja Yunus Ali University, Sirajganj 6751, Bangladesh \\ ${ }^{2}$ Department of Pharmacy, State University of Bangladesh, 77 Satmasjid Road, Dhanmondi \\ Dhaka 1205, Bangladesh
}

(Received: December 14, 2021; Accepted: January 21, 2022; Published (web.): January 29, 2022)

\begin{abstract}
Hospital pharmacy and graduate pharmacists are part and parcel of a proper healthcare system. This study aims to assess Bangladesh's current hospital pharmacy practice and drug management system. A face-to-face interview-based survey was designed, and 15 hospitals of Khulna Division of Bangladesh were subjected to evaluation by a close-ended questionnaire containing 17 questions regarding hospital pharmacy practice and drug management system. Among 15 hospitals, 67\% had hospital pharmacy services, whereas $47 \%$ had "C" grade pharmacists, and $53 \%$ of hospitals had no narcotic drug locker. Surprisingly, $87 \%$ of hospitals had no PTC (pharmacy and therapeutic committee), and $40 \%$ had no control over drug abuse. Besides, only $6.67 \%$ of hospitals had graduate pharmacists (A grade pharmacists), and 33\% had no pharmacists. Furthermore, $67 \%$ of hospitals provided drug-using information, and $60 \%$ of hospitals provided no dosing information to their patients. Moreover, $40 \%$ did not maintain the record for expired products and had no "not for sale" tag for expired or damaged medicines. The current study findings suggest that the respective authorities must revisit the current healthcare system and take immediate initiatives to appoint graduate pharmacists in every hospital to improve the medical service with a proper drug management system.
\end{abstract}

Key words: Hospital pharmacy, graduate pharmacist, rational uses of drugs, pharmacy and therapeutic committee, patient care, pharmacy practice.

\section{Introduction}

A hospital pharmacy is anticipated to optimize the small-scale drug manufacturing, dispensing, and distribution and develop policy and procedures to ensure the safe distribution of medications and associated supplies to inpatients and outpatients (Alsultan et al., 2012). Hospital pharmacies typically carry a more comprehensive selection of pharmaceuticals than community pharmacies, along with more specialist and experimental medication. A hospital pharmacy is essential because it plays a vital role in adherence to treatment.

Generally, graduate pharmacists work in hospital pharmacies in developed countries. Pharmacists are healthcare experts who practice pharmacy, including administering prescribed medications, assessing drug-related problems, and counseling patients on the effects and appropriate use of prescription medications and nutraceuticals (Jakaria et al., 2021). Pharmacists have received clinical experience and adequate expertise, which allows them to provide high-quality service in hospital pharmacy settings. Graduate pharmacists play a pivotal role in ensuring patient compliance and welfare in a hospital pharmacy setting. Improvisational production, prescription evaluation, and patient advice are just a few of the divisions that can only be managed by graduates of pharmacy school. When it comes to 
hospitals, clinically experienced graduate pharmacists are primarily in charge of supervising and providing assistance to them (Beso et al., 2005).

In Bangladesh, hospital pharmacy is neglected (Labu, 2013). Graduate Pharmacists are limited to only manufacturing drugs in Bangladesh, and they have no opportunity to work on other crucial services to improve the health care system (Jakaria et al., 2021; Hossain, 2020). Government hospitals in Bangladesh have few hospital pharmacists, and the country did not introduce hospital pharmacy services run by graduate pharmacists (Paul et al., 2015). However, some private hospitals like Apollo Hospital, Square Hospital, United hospital, Sheikh Russel Gastroliver Institute \& Hospital, etc. have established hospital pharmacy department, where graduate pharmacists worked in $24 \mathrm{~h}$ successfully, and it was proved by the local survey that their quality of treatment and services to the patient is quite appreciable (Saha et al., 2017). Challenges resulting from an increment in the number of medicines available and lack of adherence have changed the conversation of pharmacists toward a caring attitude. As a result of this situation, the pharmacy practice has come to be viewed as an incredibly significant vocation in the interdisciplinary team that provides medical services (Paul et al., 2014). In emerging regions, the pharmacy occupation is indeed falling behind in comparison to industrialized nations in the sense that pharmacy practitioners have never been acknowledged as a section of the medical team, neither by the population nor by healthcare practitioners (Said et al., 2020)

Recently, investigators in the United Kingdom revealed that the majority of pharmacists were committed to producing advice to physicians as well as patient (Paul et al., 2014). Clinical pharmacy services need to be available to all patients as part of normal care, according to the Society of Hospital Pharmacists of Australia (SHPA), because clinical pharmacists play significant role in minimizing the frequency of adverse medication events (Roy et al., 2015)
According to the research conducted by RezwanUl-Haque et al. (2018), pharmaceutical caregivers have a considerable positive influence on healthbased on measurement and health care expenses over the long run. It has been shown that the benefits provided by pharmacists and their cooperation in patient-centered care have a significant impact on health and economic outcomes, adverse drug reactions, the standard of living, as well as morbidity and mortality. Hospital pharmacists are responsible for providing essential treatments by ensuring that medications are administered appropriately for each individual's age, gender, body weight, and therapeutic state (Rezwan-Ul-Haque et al., 2018). The inclusion of a pharmacist on a reply department round was found to be beneficial. In the scenario of patients taking many drugs, having health complications, or having other characteristics that make dispensing difficult, pharmacists can guide choosing the most suitable and effective prescribed medication to avoid adverse drug effects (Shill and Das, 2011). Because of their exposure to personal contact, pharmacists can confine drug interactions and educate patients concerning their illness and medicine, for example, by presenting knowledge, counseling, and guidance concerning pharmacological interventions, among other things (Shill and Das, 2011).

Drug management and drug distribution in the public sector in Bangladesh is a very difficult process. Without an electronic drug management information system, it is very difficult to be able to communicate about short-dated drugs in one facility and a near stock-out situation in another facility. Drug stores were often cramped and poorly ventilated. The storekeepers often had little knowledge of the stock situation on the wards or in the outpatient dispensary. The stock was generally well maintained in the Out-patient Department (OPD) dispensary under the charge of diploma pharmacists. However, drug management and drug distribution were much less well managed, with poor storage conditions and poorly maintained stock records (Medicine in health care delivery in Bangladesh, 2014). Therefore, in this study, our 
purpose is to investigate the hospital pharmacy practice and drug management system among the hospitals of several districts of the Khulna Division in Bangladesh.

\section{Materials and Methods}

Study design: A cross-sectional survey containing 17 questions was designed and segmented into two sections (A and B). Sections A and B included hospital pharmacy practice based-questions and drug management-related questions, respectively, to investigate the current hospital pharmacy practice and drug management system. The questions were adopted from the previously published literature (Saha et al., 2017; Paul et al., 2014; Al-sultan et al., 2012; Bond et al., 2002; Westbrook et al., 2013; Pedersen et al., 2011). The questionnaire was initially drafted in English and then translated into Bangla through a forward and backward translation process to make it better understandable for the respondents (Bari et al. 2021; Hossain et al., 2021a; Hossain et al., 2022).

Study population, sampling and data collection: A convenient sampling method was applied to collect opinions from the corresponding hospital representative through the designed questionnaire (Saha et al., 2017; Paul et al., 2014). This study was conducted from 15 hospitals in Jashore, Satkhira, Khulna, Kushtia, and Magura. Among these hospitals, one was a government hospital, one was an Upazilla health complex and the rest of the hospitals were privately owned. This study was conducted at Sadar, Thana, and Upazilla levels. All respondents were hospital supervisors, hospital managers, hospital receptionists, and hospital pharmacists. The data were collected from May 15, 2021, to June 15, 2021. This study was conducted by face-to-face interview. It is required to note that the study has followed all the ethical protocols and guidelines delineated by the World Medical Association (WMA) Declaration of Helsinki (WMA, 2020).

Data analyses: In this study all hospitals were symbolized as "A", "B", "C", "D", "E", "F", "G", "H", "I", "J”, “K”, “L”, “M”, "N", “O”. All data were analyzed by Microsoft Excel version 2013 with pivot chart and pie chart. The per-education, experience and the attendants' dispensing routines in medical centers or functional pharmacies were all reviewed. Besides, the understanding of hospital pharmacies, widely distributed pharmaceuticals, and the impact of various criteria on prescribing practices as well as their readiness to have a certified pharmacist at their medical centers, were all assessed.

\section{Results and Discussion}

The current study examined the prevailing hospital pharmacy practice and the available drug management system in Bangladesh. In Table 1, Hospital pharmacy practice has been tabulated. Among 15 hospitals, hospitals A, B, C, D, F, H, J, K, $\mathrm{M}$, and $\mathrm{O}$ had sufficient infrastructure (Refrigerator, CCTV security), and others do not have sufficient infrastructure. Only "M" hospital has an "A" grade pharmacist in its hospital pharmacy. Besides, "B" and "K" hospitals had "B" grade pharmacists. Alongside, seven hospitals (A, C, D, F, H, J, and O) had "C" grade pharmacists, and the rest of the hospitals had no pharmacist. Except "E" hospital, "G" hospital, "I" hospital, "L" hospital, and "N" hospital, all hospitals provided drug-using information. Six of the 15 hospitals (40\%) offered dosing information to the customers. Within the professional section of hospitals A, B, C, D, F, J, K, M, and O, there was separate storage space. However, E, G, H, I, L, and N hospitals had no separate storage room within the professional area. The hospitals E, G, H, I, L, and N did not label expired or damaged medications as "not for sale" but A, B, C, D, F, J, K, M, and O hospitals supplied the label for expired or damaged medications. Seven hospitals (B, C, F, J, K, M, and $\mathrm{O})$ was keeping medicine on the floor or hallway, whereas the other eight hospitals (A, D, E, G, H, I, L, and $\mathrm{N}$ ) did not. Other hospitals, except for E, G, H, I, $\mathrm{L}, \mathrm{N}$ hospitals, did not keep a record of all expired products.

In Table 2, drug management and activity of hospital authorities and job holders have been summarized. Among 15 hospitals, 14 hospitals staff 
were aware of their responsibility. Only staff of hospital "E" had no awareness of their responsibilities. Ten hospitals (67\%) had hospital pharmacy service available. Five hospitals had no hospital pharmacy services which were designated as hospital "E", hospital "G", hospital "I", hospital "L", hospital "N". Eight hospitals (53\%) had no narcotic drug lockers, which is a very concern issue. However, Hospitals “A”, "B", "D”, "F", “J”, “K”, and " $\mathrm{M}$ " had narcotic drug lockers. In-patient and outpatient dispensing services were provided in only seven hospitals which are "A", "B", "C", "D", "F", "J", "M". Hospitals "H" and "L" had only

Table 1. Hospital pharmacy practice of 15 hospitals in Khulna Division of Bangladesh.

\begin{tabular}{|c|c|c|c|c|c|c|c|c|}
\hline $\begin{array}{l}\text { Code of } \\
\text { Hospital }\end{array}$ & Infrastructure & $\begin{array}{l}\text { Presence of } \\
\text { pharmacist }\end{array}$ & $\begin{array}{l}\text { Does it } \\
\text { provide drug } \\
\text { using } \\
\text { information? }\end{array}$ & $\begin{array}{l}\text { Does it } \\
\text { provide } \\
\text { dosing info } \\
\text { to the } \\
\text { customers? }\end{array}$ & $\begin{array}{l}\text { Does it separate } \\
\text { storage place } \\
\text { within the } \\
\text { professional } \\
\text { area? }\end{array}$ & $\begin{array}{l}\text { Does it tag } \\
\text { expired/dama } \\
\text { ged } \\
\text { medicines- } \\
\text { "not for sale"? }\end{array}$ & $\begin{array}{l}\text { Does it store } \\
\text { medicine on } \\
\text { the floor or } \\
\text { passageway } \\
?\end{array}$ & $\begin{array}{l}\text { Do they } \\
\text { maintain a } \\
\text { record for } \\
\text { all expired } \\
\text { products? }\end{array}$ \\
\hline $\begin{array}{l}\text { Hospital } \\
\text { "A" }\end{array}$ & $\begin{array}{l}\text { Refrigerator, } \\
\text { CCTV security }\end{array}$ & $\begin{array}{l}\text { "C" grade } \\
\text { pharmacist }\end{array}$ & Yes & No & Yes & Yes & No & Yes \\
\hline $\begin{array}{l}\text { Hospital } \\
\text { "B" }\end{array}$ & $\begin{array}{l}\text { Refrigerator, } \\
\text { CCTV security }\end{array}$ & $\begin{array}{l}\text { "B" grade } \\
\text { pharmacist }\end{array}$ & Yes & Yes & Yes & Yes & Yes & Yes \\
\hline $\begin{array}{l}\text { Hospital } \\
\text { "C" }\end{array}$ & $\begin{array}{l}\text { Refrigerator, } \\
\text { CCTV security }\end{array}$ & $\begin{array}{l}\text { "C" grade } \\
\text { pharmacist }\end{array}$ & Yes & No & Yes & Yes & Yes & Yes \\
\hline $\begin{array}{l}\text { Hospital } \\
\text { "D" }\end{array}$ & $\begin{array}{l}\text { Refrigerator, } \\
\text { CCTV security }\end{array}$ & $\begin{array}{l}\text { "C" grade } \\
\text { pharmacist }\end{array}$ & Yes & No & Yes & Yes & No & Yes \\
\hline $\begin{array}{l}\text { Hospital } \\
\text { "E" }\end{array}$ & No & No & No & No & No & No & No & No \\
\hline $\begin{array}{l}\text { Hospital } \\
\text { "F" }\end{array}$ & $\begin{array}{l}\text { Refrigerator, } \\
\text { CCTV security }\end{array}$ & $\begin{array}{l}\text { "C" grade } \\
\text { pharmacist }\end{array}$ & Yes & No & Yes & Yes & Yes & Yes \\
\hline $\begin{array}{l}\text { Hospital } \\
\text { "G", }\end{array}$ & No & No & No & No & No & No & No & No \\
\hline $\begin{array}{l}\text { Hospital } \\
\text { "H" }\end{array}$ & $\begin{array}{l}\text { Refrigerator, } \\
\text { CCTV security }\end{array}$ & "C" grade & Yes & Yes & No & No & No & No \\
\hline Hospital "I" & No & No & No & No & No & No & No & No \\
\hline Hospital "J" & $\begin{array}{l}\text { Refrigerator, } \\
\text { CCTV security }\end{array}$ & $\begin{array}{l}\text { "C" grade } \\
\text { pharmacist }\end{array}$ & Yes & Yes & Yes & Yes & Yes & Yes \\
\hline $\begin{array}{l}\text { Hospital } \\
\text { "K" }\end{array}$ & $\begin{array}{l}\text { Refrigerator, } \\
\text { CCTV security }\end{array}$ & $\begin{array}{l}\text { "B" grade } \\
\text { pharmacist }\end{array}$ & Yes & Yes & Yes & Yes & Yes & Yes \\
\hline $\begin{array}{l}\text { Hospital } \\
\text { "L" }\end{array}$ & No & No & No & No & No & No & No & No \\
\hline $\begin{array}{l}\text { Hospital } \\
\text { "M" }\end{array}$ & $\begin{array}{l}\text { Refrigerator, } \\
\text { CCTV security }\end{array}$ & $\begin{array}{l}\text { "A" grade } \\
\text { pharmacist }\end{array}$ & Yes & Yes & Yes & Yes & Yes & Yes \\
\hline $\begin{array}{l}\text { Hospital } \\
\text { "N" }\end{array}$ & No & No & No & No & No & No & No & No \\
\hline $\begin{array}{l}\text { Hospital } \\
\text { "O" }\end{array}$ & $\begin{array}{l}\text { Refrigerator, } \\
\text { CCTV security }\end{array}$ & $\begin{array}{l}\text { "C" grade } \\
\text { pharmacist }\end{array}$ & Yes & Yes & Yes & Yes & Yes & Yes \\
\hline
\end{tabular}

inpatient dispensing service and Hospitals " $\mathrm{I}$ ", "K", and "O" provided only outpatient service. However, Hospitals "E", "G", and "N" was not providing any in-patient or outpatient service. But there had the most concerning issue that only two Hospitals had drug and therapeutics committee. They were hospitals "B", "M". Hospital "B" chief pharmacist was involved in the hospital drug and therapeutic committee. In hospital " $M$ ", the pharmacist is involved with this committee. The rest of the hospitals $(87 \%)$ had no hospital drug and therapeutic committee. Besides seven hospitals (47\%) did not 
have any hospital formulary management. In the hospital of "A", "D", "F", "J", and "O", the physician was involved with hospital formulary management and in hospitals "B" and "M", a representative from the pharmacy department was involved in formulary management system. As well as, in hospital "K", medical staff was involved. Except hospitals "G",
"H", "N" all hospitals had a waste management system. Hospital "A", "B", "C", "D”, "F", "J", "K”, "M", and "O" had controlled drug abuse, and others had no control over the drug abuse. Furthermore, the obtained results after the univariate analysis of the dataset have been shown in Figure 1.

Table 2. Drug management and activity of 15 hospitals in Khulna Division of Bangladesh.

\begin{tabular}{|c|c|c|c|c|c|c|c|c|c|}
\hline $\begin{array}{l}\text { Code of } \\
\text { Hospital } \\
\text { name }\end{array}$ & $\begin{array}{l}\text { Number } \\
\text { of } \\
\text { hospital- } \\
\text { bed }\end{array}$ & $\begin{array}{l}\text { Are all of staff } \\
\text { aware of their } \\
\text { responsibility? }\end{array}$ & $\begin{array}{l}\text { Is there a } \\
\text { hospital } \\
\text { pharmacy } \\
\text { service } \\
\text { available? }\end{array}$ & $\begin{array}{l}\text { Does it } \\
\text { have } \\
\text { narcotic } \\
\text { drug } \\
\text { locker? }\end{array}$ & $\begin{array}{l}\text { Does it } \\
\text { have } \\
\text { inpatient } \\
\text { and } \\
\text { outpatient } \\
\text { dispensing } \\
\text { service? }\end{array}$ & $\begin{array}{l}\text { Who is } \\
\text { involved } \\
\text { with the } \\
\text { hospital } \\
\text { drug and } \\
\text { therapeutics } \\
\text { committee? }\end{array}$ & $\begin{array}{l}\text { Who is } \\
\text { involved } \\
\text { with } \\
\text { hospital } \\
\text { formulary } \\
\text { managemen } \\
t \text { ? }\end{array}$ & $\begin{array}{l}\text { Do they } \\
\text { have a } \\
\text { waste } \\
\text { managemen } \\
\text { t system? }\end{array}$ & $\begin{array}{l}\text { Do they } \\
\text { control } \\
\text { drug } \\
\text { abuse? }\end{array}$ \\
\hline Hospital "A" & 25 & Yes & Yes & Yes & Yes & None & Physician & Yes & Yes \\
\hline Hospital "B" & 100 & Yes & Yes & Yes & Yes & $\begin{array}{l}\text { Chief } \\
\text { pharmacist }\end{array}$ & $\begin{array}{l}\text { Representat } \\
\text { ive from the } \\
\text { pharmacy } \\
\text { department }\end{array}$ & Yes & Yes \\
\hline Hospital "C" & 55 & Yes & Yes & No & Yes & None & None & Yes & Yes \\
\hline Hospital "D" & 50 & Yes & Yes & Yes & Yes & None & Physician & Yes & Yes \\
\hline Hospital "E" & 15 & No & No & No & $\begin{array}{l}\text { No service } \\
\text { is available }\end{array}$ & None & None & Yes & No \\
\hline Hospital "F" & 40 & Yes & Yes & Yes & Yes & None & Physician & Yes & Yes \\
\hline Hospital "G" & 20 & Yes & No & No & $\begin{array}{l}\text { No service } \\
\text { is available }\end{array}$ & None & None & No & No \\
\hline Hospital "H" & 30 & Yes & Yes & No & $\begin{array}{l}\text { Only in- } \\
\text { patient } \\
\text { service } \\
\text { available }\end{array}$ & None & None & No & No \\
\hline Hospital "I" & 21 & Yes & No & No & $\begin{array}{l}\text { Only out } \\
\text { patient } \\
\text { service } \\
\text { available }\end{array}$ & None & None & Yes & No \\
\hline Hospital "J" & 46 & Yes & Yes & Yes & Yes & None & Physician & Yes & Yes \\
\hline Hospital "K" & 250 & Yes & Yes & Yes & $\begin{array}{l}\text { One } \\
\text { dispensary } \\
\text { for out } \\
\text { patient }\end{array}$ & None & $\begin{array}{l}\text { Medical } \\
\text { staff }\end{array}$ & Yes & Yes \\
\hline Hospital "L", & 25 & Yes & No & No & $\begin{array}{l}\text { Only in- } \\
\text { patient } \\
\text { service } \\
\text { available }\end{array}$ & None & None & Yes & No \\
\hline Hospital "M" & 150 & Yes & Yes & Yes & Yes & Pharmacist & $\begin{array}{l}\text { Representat } \\
\text { ive from the } \\
\text { pharmacy } \\
\text { department }\end{array}$ & Yes & Yes \\
\hline Hospital "N" & 14 & Yes & No & No & $\begin{array}{l}\text { No service } \\
\text { is available }\end{array}$ & None & None & No & No \\
\hline Hospital "O" & 75 & Yes & Yes & No & $\begin{array}{l}\text { Out-patient } \\
\text { service } \\
\text { available }\end{array}$ & None & Physician & Yes & Yes \\
\hline
\end{tabular}




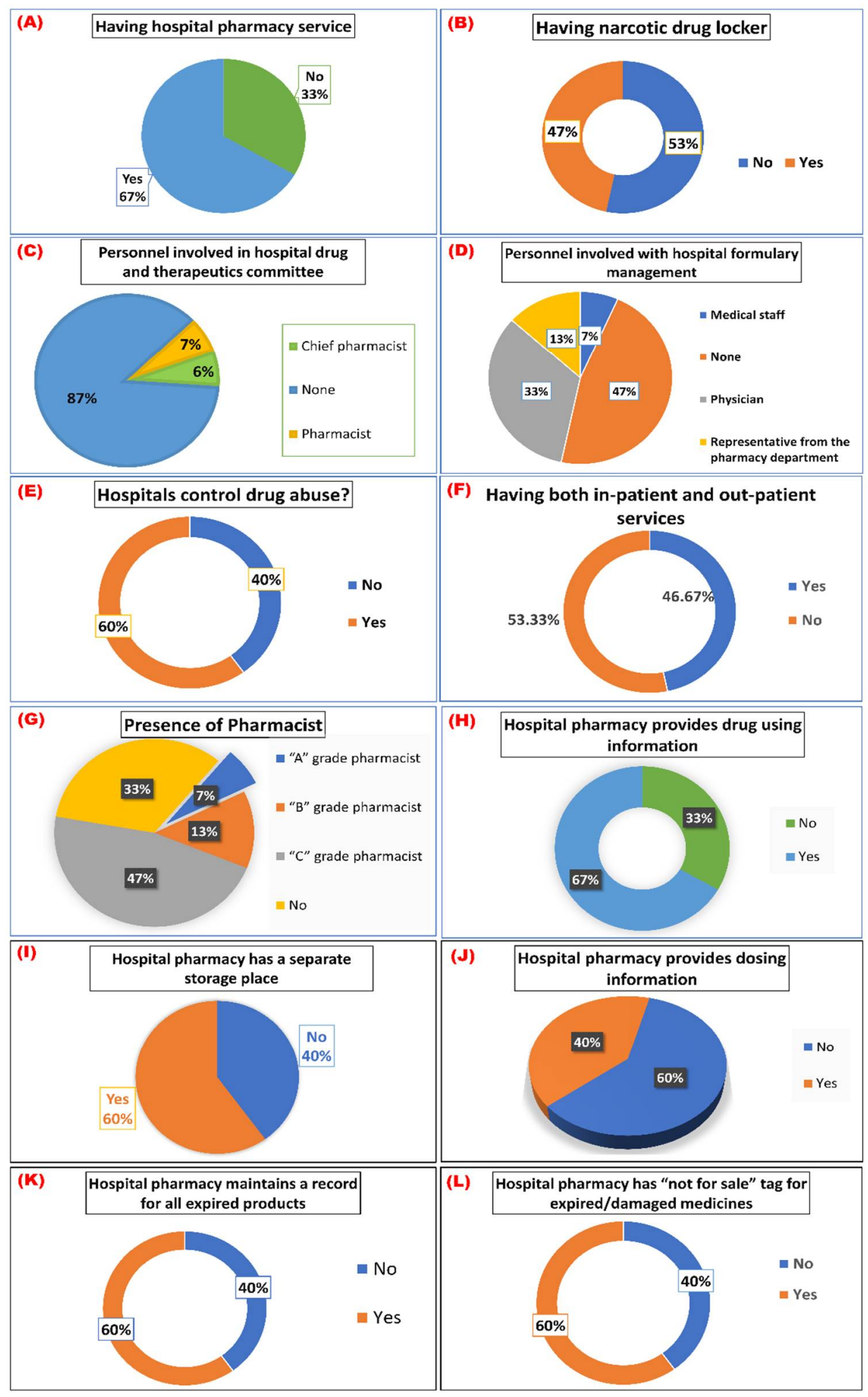

Figure 1. Current situation of the pharmacy practice and drug management systems in Bangladeshi hospitals (Khulna Division). 
This study aimed to explore practices in hospital pharmacies and drug management among 15 hospitals in the Khulna Division of Bangladesh. Pharmacists are experts in drug management and distribution, drug-drug interaction monitoring, and clinical research. Furthermore, rescheduling a patient's dose regimen can only assure logical prescribing and usage of medications, which is the primary responsibility of clinical pharmacists (Labu, 2013). According to the literature review, the profession of pharmacy is firmly established around the world, particularly in developed nations. Despite the World Health Organization's (WHO) guidelines on the role of pharmacists in clinical settings, there are still considerable variances in the practices of various nations (Anderson, 2002). This, once again, completely disregards WHO requirement, the presence of a legally competent registered pharmacist at a functioning pharmacy (Anderson, 2002).

We collected information from 15 hospitals in the Khulna Division of Bangladesh, among them about $67 \%$ of hospitals had hospital pharmacy services. Only 7\% A grade pharmacists, $13 \%$ B grade pharmacist and 47\% C grade pharmacists were appointed by the hospital authority and 33\% did not recruit any pharmacist. According to The National Drug Policy 2005 of Bangladesh, drug distribution and usage in retail pharmacies and hospitals should be supervised by certified pharmacists. However, except for a few high-level private hospitals, no graduate pharmacist works at retail pharmacies or government hospitals in Bangladesh (Paul et al., 2014). Every year, a large number of patients suffer from various abnormalities and toxicities due to taking an irrational drug and medication usage. As a result, many patients die in drug intoxications (Labu, 2013; Uddin et al., 2021). Surrey M Walton found that a scarcity of pharmacists exacerbated medication errors (Walton, 2004).

Due to a lack of certified pharmacists, $67 \%$ of hospital pharmacies provided no drug-using and drug-dosing information to consumers. It may result in drug resistance in many patients. It can be noted that $60 \%$ of hospital pharmacies had a separate storage place, 'not for sale' tag for expired/damaged medicine or maintain a record for all expired products. About $40 \%$ of hospital pharmacies had no facility for storage medicine and medicine regarding pieces of information. However, in the wards, drugs were much less well managed, with poor storage conditions and poorly maintained stock records.

In our study, more than $50 \%$ of hospitals provided both facilities of inpatient and outpatient dispensing services, and the rest of the hospitals either provided either inpatient or outpatient services. In outpatients, patients are given a prescription, with a separate slip recording the drugs to be dispensed from the OPD dispensary. The slips with the drugs recorded are then given to the pharmacy where the drugs are dispensed. The OPD pharmacies keep these slips to count up the number of drugs dispensed each day. Inpatient records consist of one sheet of paper with history, examination, and diagnosis recorded and with any lab tests, etc. attached. There is no individual patient dispensing record sheet. The record-keeping for actual dispensing of medicines to inpatients was poor and, in some circumstances, dangerous. As a result, the patient gets lower health care facilities from inpatient and outpatient dispensing services (Medicine in health care delivery in Bangladesh, 2014).

It is noted that $53 \%$ of hospitals had no narcotic drug locker. The Narcotics Control Act 1990 prohibits the import, export, sale, purchase, manufacture, processing, transport, possession, use, or any other kinds of operations of narcotic drugs except for medicinal, scientific, or legitimate industrial purposes under license, permit, or pass. According to this policy, every hospital needs a locker for controlling narcotic drugs. The number of personnel in hospital for drug and therapeutic committee is very negligible. Only $6 \%$ chief pharmacist and $7 \%$ pharmacist were appointed by the hospital authority and rest of the $87 \%$ of hospitals did not recruit any personnel.

Moreover, $7 \%$ of medical staff, $13 \%$ representatives from the pharmacy department, 33\% of physicians have been involved with hospital 
formulary management. Besides, $60 \%$ of hospitals control drug abuse and the rest of the hospitals had no control over drug abuse. These summarized data showed that there are still barriers to the continued development of the hospital pharmacy service because of the difficulty of recruitment of qualified pharmacists and other hospital personnel. The quality and scope of research into pharmacy practice must be improved in order to sustain and develop this practice into every hospital service (Calvert, 1999).

Hospital pharmacy strategies have also been shown to save money in various countries (Paul et al., 2014). Dooley et al. (2004) revealed that the yearly cost-savings linked with economically evaluated resources owing to pharmacist interventions in the 8 institutions was $\$ 4447947$ (AUS). It is noted that $\$ 23$ was saved for every $\$ 100$ spent on a pharmacist to begin an intervention. The addition of a part-time pharmacist to the ICU in Malaysia resulted in a $\$ 4014$ (US) savings over one month (Zaidi et al., 2003).

There is evidence that pharmacists may enhance patient care while lowering health-care costs, and as a result, they have begun to economically justify their role in inpatient clinical care (Paul et al., 2014). To overcome this problem, it has been suggested that more "A" grade pharmacists should be appointed in the hospital pharmacies. The government should take the initial steps by mandating the presence of at least one graduate pharmacist in all hospitals. Bangladesh should also implement policies and strategies to increase the use of " $\mathrm{A}$ " grade pharmacists in health care and public health activities, following the International Pharmaceutical Federation (FIP) and World Health Organization (WHO) standards for developing countries (Organization, 1998; Abdelhamid et al., 2008).

Pharmacists are the third biggest group of healthcare professionals and provide a readily accessible point of contact for patients. Recognizing this, numerous governments have decided to improve pharmacist practice (Haag et al., 2016; Kamal et al., 2015) to improve patient care. (Auta et al., 2018; Famiyeh and McCarthy, 2017). When the government of Bangladesh tries to promote the healthcare system, it may be the country's largest folly to lack pharmacists in the health care system (Jakaria et al., 2021; Hossain, 2020).

It is also suggested to hospital administrators that a hospital pharmacy should be established to assure patient compliance and therapeutic outcomes, as well as to provide worldwide quality healthcare services. Pharmacists and pharmacy services are critical components of the healthcare system. To provide the best treatment possible, doctors, pharmacists, nurses, and other healthcare professionals must collaborate (Paul et al., 2014).

Pharmacists in Bangladesh struggled a lot when started to do these activities in a hospital for the first time as it was a new concept. Doctors, nurses, and other healthcare providers got satisfied when they have observed that pharmacists have ultimately made their task easier and ensured patient safety (Hossain, 2020; Hossain et al., 2021b). Besides, Hospitals have got benefits through the proper management of medicines and the Pharmacy Department became second contributory after Consultation Department in the annual profit margin in a hospital (Paul et al., 2014).

Findings from this interview-based study might be landscape for the policymakers and pharmacy practitioners looking for updated statistics on the proper pharmacy practice parameters and drug management system in Bangladesh. However, the current study did not cover the whole country's data to reveal the exact scenario. Besides, no rigorous statistical method has not been used during the data analysis.

\section{Conclusion}

According to the study, the main problem is that graduate pharmacists are not employed in those hospitals. But to improve the healthcare system, every hospital's human resources should have a graduate pharmacist on services. Then they could give quality healthcare access. Lawmakers in charge of education and healthcare assistance, including the Ministry of Health and Family Welfare (MOHFW), 
the Directorate General of Drug Administration (DGDA), the Pharmacy Council of Bangladesh (PCB), and other governing bodies, should reorganize the healthcare system, should assure the hospital pharmacy service, immediately recruit of hospital pharmacists, and intervene to ensure appropriate guidance and training to the hospital pharmacists to minimize the medication errors and improve the healthcare system and patient safety.

\section{Conflict of interest}

There are no conflicts of interest declared by the authors.

\section{Funding}

To conduct this study, the authors received no funding from any agency, institute, or individual.

\section{References}

Abdelhamid, E., Awad, A., and Gismallah, A. 2008. Evaluation of a hospital pharmacy-based pharmaceutical care services for asthma patients. Pharm. Pract. 6, 25-32.

Alsultan, M.S., Khurshid, F., Mayet, A.Y. and Al-Jedai, A.H. 2012. Hospital pharmacy practice in Saudi Arabia: Dispensing and administration in the Riyadh region. Saudi Pharm. J. 20, 307-315.

Anderson, S. 2002. The state of the world's pharmacy: A portrait of the pharmacy profession. J. Interprof. Care. 16, 391-404.

Auta, A., Strickland-Hodge, B., Maz, J., and David, S. 2018. Pharmacist prescribing: A cross-sectional survey of the views of pharmacists in Nigeria. Int. J. Pharm. Pract. 26, 111-119.

Bari, M., Hossain, M., Ahmmed, F., Sarker, M., Rahman, M., Khandokar, L., Chaithy, A.P., Aziz, F., Mitra, S., Emran, T.B. and Islam, M.R. 2021. Knowledge, perception, and willingness towards immunization among Bangladeshi population during COVID-19 vaccine rolling period. Vaccines, 9, 1449.

Bond, C.A., Raehl, C.L. and Franke, T. 2002. Clinical pharmacy services, hospital pharmacy staffing, and medication errors in United States hospitals. Pharmacother. 22, 134-147.

Calvert R. T. 1999. Clinical pharmacy-a hospital perspective. British J. Clin. Pharmacol. 47, 231-238.
Dooley, M. J., Allen, K. M., Doecke, C. J., Galbraith, K. J., Taylor, G. R., Bright, J. and Carey, D. L. 2004. A prospective multicentre study of pharmacist initiated changes to drug therapy and patient management in acute care government funded hospitals. British J. Cli. Pharmacol. 57, 513-521.

Famiyeh, I.M. and McCarthy, L. 2017. Pharmacist prescribing: A scoping review about the views and experiences of patients and the public. Res. Soc. Adm. Pharm. 13, 1-16.

Haag, J.D., Davis, A.Z., Hoel, R.W., Armon, J.J., Odell, L.J., Dierkhising, R.A. and Takahashi, P.Y. 2016. Impact of pharmacist-provided medication therapy management on healthcare quality and utilization in recently discharged elderly patients. Am. Health Drug Benef. 9, 259-268.

Jakaria, M., Azam, S., Siddiqui, S.A., Hoq, M.I. and Islam, M.S. 2021. Irrational pharmacy practice and inadequate health care services in Bangladesh: A lesson learned from COVID-19 pandemic. J. Basi. Cli. Physiol. Pharmacol. 32, 129-130.

Kamal, S., Holmberg, C., Russell, J., Bochenek, T., Tobiasz-Adamczyk, B., Fischer, C. and Tinnemann, P. 2015. Perceptions and attitudes of Egyptian health professionals and policy-makers towards pharmaceutical sales representatives and other promotional activities. PloS One, 10, e0140457.

Hossain, M.J. 2020. Impact of COVID-19 pandemic among health care providers in Bangladesh: a systematic review. Bangladesh J. Infect. Dis. 7 (suppl_2), S8S15.

Hossain, M.J., Ahmmed, F., Rahman, S.A., Sanam, S., Emran, T.B. and Mitra, S. 2021a. Impact of online education on fear of academic delay and psychological distress among university students following one year of COVID-19 outbreak in Bangladesh. Heliyon, 7, e07388.

Hossain, M.J., Rahman, S.M.A., Emran, T.B., Mitra, S., Islam, M.R. and Dhama, K. 2021b. Recommendation and roadmap of mass vaccination against COVID-19 pandemic in Bangladesh as a lower-middle-income country. Arc. Razi Institute, 76, 1793-1800.

Hossain, M.J, Ahmmed, F., Sarker, M.M.R., Sarwar, S., Bari, M., Khan, M.R., Shahriar, S., Rafi, M.O., Emran, T.B. and Mitra, S. 2022. Factors associated with underprivileged e-Learning, session jam phobia, and the subsequent mental distress among students following the extended university closure in Bangladesh. Front. Public Health. doi: 10.3389/fpubh.2021.807474 [In Press] 
Labu, Z. 2013. Present status of pharmacy education and future prospects and challenge of pharmacy practice in Bangladesh. J. Drug Disc. Therapeut. 1, 1-9.

Medicines in Health Care Delivery in Bangladesh. 2014. Available from: https://cdn.who.int/media/docs/ default-source/searo/hsd/edm/csa-bangladesh-situational-analysis-2015.pdf?sfvrsn=941031d3_2

(Accessed date: December 1, 2021)

Organization, W. H. 1998. The Role of the pharmacist in self-care and self-medication: Report of the 4th WHO consultative group on the role of the pharmacist, The Hague, The Netherlands, 26-28 August 1998.

Paul, T.R., Rahman, M.A., Biswas, M., Rashid, M. and Islam, M.A.U. 2014. Practice of hospital pharmacy in Bangladesh: current perspective. Bangladesh Pharm. J. 17, 187-192.

Pedersen, C.A., Schneider, P.J. and Scheckelhoff, D.J., 2012. ASHP national survey of pharmacy practice in hospital settings: dispensing and administration2011. Am. J. Health-System Pharm. 69, 768-785.

Rezwan-Ul-Haque, M., Kabir, L., and Haque, M. E. 2018. a cursory look at the pharmacy practice and pharmaceutical care in the public hospital (s) of Bangladesh: a case study. Biores. Commun. 4, 500505 .

Roy, D.N., Rajib, S.S., Farzana, F., Islam, S., Hossain, M.M. and Mondol, D. 2015. The current scenario of hospital pharmacy practice in Bangladesh: a cross sectional survey. Int. J. Cur. Eng. Tech. 5, 2111-2116.

Saha, T., Bhuiya, R.H., Masum, Z.U., Islam, M.R. and Chowdhury, J.A. 2017. Hospital pharmacy management system and future development approaches in Bangladeshi hospital. Bangladesh Pharm. J. 20, 180-187.
Said, A., Hussain, N. and Abdelaty, L.N. 2020. Physicians' and pharmacists' perception and practice of hospital pharmacist professional role in Egypt. Int. J. Pharm. Prac. 28, 491-497.

Shill, M.C., and Das, A.K. 2011. Medication practices in Bangladesh-roles of pharmacists at current circumstances. Int. J. Pharm. Pharm. Sci. 3, 5-8.

Uddin, T.M., Chakraborty, A.J., Khusro, A., Zidan, B.R.M., Mitra, S., Emran, T.B., Dhama, K., Ripon, M.K.H., Gajdács, M., Sahibzada, M.U.K. and Hossain, M.J. and Koirala, N. 2021. Antibiotic resistance in microbes: History, mechanisms, therapeutic strategies and future prospects. J. Infect. Public Health, 14, 1750-1766.

Walton, S.M. 2004. The pharmacist shortage and medication errors: issues and evidence. J. Med. Sys. 28, 63-69.

Westbrook, J.I., Li, L., Georgiou, A., Paoloni, R. and Cullen, J., 2013. Impact of an electronic medication management system on hospital doctors' and nurses' work: a controlled pre-post, time and motion study. $J$. Am. Med. Infor. Assoc. 20, 1150-1158.

WMA. 2020. WMA declaration of Cordoba on patientphysician relationship. Available from: ttps://www.wma.net/policies-post/wma-declaration-ofcordoba-on-patient-physician-relationship/ (Accessed: December 1, 2021).

Zaidi, S.T.R., Hassan, Y., Postma, M.J., and Hain, N.S. 2003. Impact of pharmacist recommendations on the cost of drug therapy in ICU patients at a Malaysian hospital. Pharm. Wor. Sci. 25, 299-302. 